Мистецтво, історія, сучасність, теорія: Зб. наук. пр. з мистецтвознав. i культурології. Київ : ФЕНІКС, 2014. Вип. 10. С. 120-144.

6. Проскуряков В.І., Ярема Д.Р. Сценографія як складова монументально-декоративного мистецтва інтер'єру театру. Вісник Національного університету «Львівська політехніка». Львів : Архітектура. 2012. № 728. C. 104-108.

7. Триколенко С. Т. Метафоричне вирішення архітектурного середовища на театральній сцені. Вісник Харківської державної академії дизайну і мистеитв. Харків. 2012. № 10. С. 136-140

8. Фіалко В. Образна мова сценічного мистецтва в осмисленні теоретиків і практиків театру. Науковий вісник Київського національного

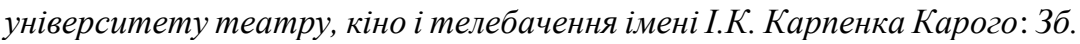
наук. пр. Київ, 2018. Вип. 22. С. 42-47.

9. Френкель М. Современная сценография (некоторые вопросы теории и практики). Київ : Мистецтво, 1980, 172 с.

10. Шеповалов В. Сценография в художественной целостности спектакля : автореферат дис. канд. искусствоведения : 17.00.01. Санкт-Петербург, 1986. 19 с.

\title{
DOI https://doi.org/10.30525/978-9934-26-178-7-43
}

\section{ПРИНЦИПИ ФОРМОТВОРЕННЯ ОБ'ЄКТІВ ЛЕНД-АРТУ}

\author{
Славінська Г. М. \\ стариий викладач кафедри основ архітектури \\ Сандркіна О. Л. \\ асистент кафедри основ архітектури \\ Стоянова Г. $О$. \\ асистент кафедри основ архітектури \\ Придніпровська державна академія будівниитва та архітектури \\ м. Дніпро, Україна
}

Одним з викликів сучасності людству постає проблема скорочення ресурсів. Подальше виживання людства без перебільшення можливе лише за умови нового, екологічного мислення. Провідну роль в формуванні свідомого та відповідального ставлення до оточуючого середовища має відігравати сучасна освіта, зокрема освіта архітектурна. У ДВНЗ ПДАБА на кафедрі Основ архітектури розроблено методику 
викладання дисципліни Архітектурна композиція. В процесі виконання низки завдань, формуються навички роботи з лінією, плямою, тоном, кольором, фактурою, графічними матеріалами та техніками.

Елементи композиційної мови $є$ загальними для творів графіки й дизайну, мистецтва фотографії, живопису, скульптури, предметного дизайну, архітектурних об’єктів і середовищних просторів, беруть участь у формотворенні на площині, в обсязі, і просторі [1, с. 11].

Розглянуті вище елементі зображувальної мови студенти опановують при виконанні завдання «Ленд-арт» в рамках дисципліни «Архітектурна композиція», метою якої є розвиток креативного мислення, аналітичний підхід в роботі та обгрунтування рішень, впровадження концепції образу в об’ ємно-просторову композицію. Виконуючи завдання, спрямоване на дослідження організації простору, студенти на власному досвіді переконуються, що середовищний простір може мати не тільки певні фізичні характеристики, але й впливати на емоційний стан людини. Під час виконання завдання відбувається практичне підтвердження впливу різних чинників (таких як колір, форма, ритм, пропорції, контраст, співвідношення тощо) на виразність композиції. Досягнення образності залежить від уміння автора передати певний емоційний стан, характерний психологічний образ.

Ідея набуває форми базуючись на об'єктивному та суб'єктивному досвіді. Який може не перетинатися зі свідомістю оточення, але базуватися на загальнодоступних знаннях та поняттях. У цьому випадку вона має бути максимально просто обгрунтованою, у вигляді тексту чи графічно.

Бажано звернути увагу на «відчутні й невловимі властивості місця» (за Симон Анвін): світло й тінь, їх роль у сприйнятті об'єкту, відбиття, текстура, матеріал, настрій, місце розташування, ландшафт, геометрія, масштаб, колір, психологія сприйняття кольору, звук / акустичні ефекти (храм, ліс), запах (кав'ярня, бібліотека), час [2, с. 49]. Можливе застосування графічного аналізу парних композиційних понять: площина - простір, колір - ахроматика; контраст - нюанс, геометрія - біоніка; компактний - розсереджений; структурний - вільний, простий - складно організований. Фізичні властивості навколишнього світу, що можуть підкреслити особливість: сила тяжіння, земля, повітря, вода, простір, клімат тощо.

Важливою складовою стає знайомство студентів 3 напрацюваннями митців з ленд-арту. При обговоренні прикладів сучасного мистецтва підкреслюється орієнтованість на увагу до об'єктів природної й рукотворної реальності, їх аналізу й вивченню, що належить до більш загальних моделей композиційного творення. 
Основою мистецтва ленд-арту $є$ принцип так званої доповненої реальності, інтеграція художніх елементів в існуюче природне середовище, використання природніх явищ та процесів у якості складових певного художнього образу.

Витвори мистецтва ленд-арту можуть бути як повністю 3 природніх елементів (таких як каміння, земля, сухі гілки, рослини, вода), що прив'язані до певного ландшафтного об'єкту (схил, галявина, струмок тощо), так і штучні, привнесені в природне середовище, що в подальшому існують та змінюються під зовнішнім впливом природних явищ- повітря, сонячного світла, води. Виконуються, як на відкритій та віддаленій місцевості, залишені впливу природних сил, так і в рекреаційний зонах населених пунктів, розраховані на безпосереднє сприйняття та взаємодію із глядачами.

Роботи зазвичай нестійкі, недовговічні. Існують в певний проміжок часу, та зберігаються тільки на фото та відео зйомках (рис.1.).

Таким чином сьогодні ленд-арт послуговує зв'язком між глядачем та мистецтвом, нагадуючи про взаємозалежність людини та природи.
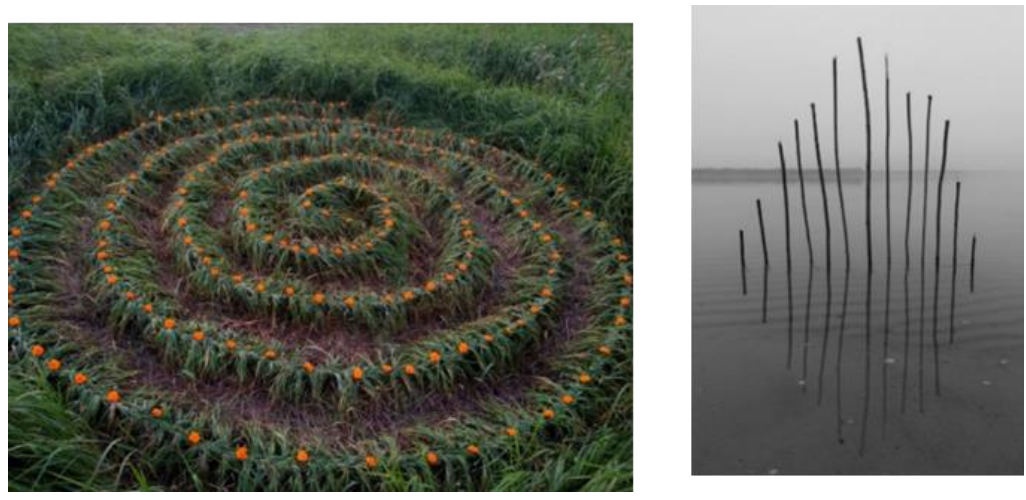

Рис. 1. Роботи студентів 2-го курсу ДВНЗ ПДАБА

Важливим фактором для створення ленд-арту $\epsilon$ ознайомлення 3 вихідною ситуацією. Аналіз середовища (пейзажу) в якому створюватиметься композиція, варто звернути увагу на властивості пейзажу:

\section{1. Масштаб простору}

- відкритість простору (поляни, луки, водоймища, площі)

- закритість (ліс, густий парк, житлова забудова) 
- пропорційне співвідношення до сусідніх об’єктів (посадка, поле, забудова)

- ступінь перспективного розкриття пейзажу

- коротка глибина перегляду до 150 м

- середня глибина перегляду від 150 до 400 м

- глибина, що далеко проглядається, від 400 м

2. Рельєф

- розвиток простору по горизонталі (алея, просіка, вулиця, бульвар)

- розвиток простору по вертикалі (підпірні стінки, пагорби, сходи, стіни, стовбури дерев)

- робота з акцентуванням рельєфу або використанням його як об'єкта (інженерне гео формування грунту)

\section{3. Оточення (природне, антропогенне)}

- екологічний фактор

- використання як основи існуючі матеріали та поверхні

- використання матеріалів конкретного місця для створення композиції

- використання сторонніх засобів і матеріалів (нитки, фарба)

\section{4. Доступність території}

- географічне розташування території відносно прилеглих пунктів населення

- транспортна інфраструктура

- юридичний статус території (заповідник, приватний парк, міський простір)

- геодинаміка рельєфу та водна структура території (яр, водоймище, болото, хиткі піски)

\section{5. Соціокультурний фактор}

- чисельність населення

- вікова та гендерна структура

- адміністративне становище території

- національний, мовний та релігійний склад населення

- соціальна активність та пасивність території

6. Економіко - психологічний фактор

- економічна доцільність об'єкту

- психоемоційний фактор району (занедбані території, відтік населення, злочинність)

- економічна активність та пасивність території

Необхідно розуміти, що залежно від факторів середовища, необхідно по-різному працювати з майбутньою композицією.

У пасивному районі з високою злочинністю, потрібен об’єкт на відкритому майданчику, з важливим соціальним посилом розрахованим 
на приплив уваги різноманітних груп населення, де різні соціальні групи зможуть порозумітися.

У заповіднику, далеко від міста, куди люди потрапляють цілеспрямовано, приїжджаючи подивитися на мінімально змінений ландшафт, 3 використанням місцевих матеріалів, що зберігають безпосередньо природу, потрібне нюансне вторгнення, оскільки юридичний статус території не дозволить створити щось, що порушує екологію ділянки. Але при цьому можна використовувати більш просторові та масштабні, при цьому тимчасові інсталяції ленд-арта, які оновлюватимуться залежно від сезону.

\section{Література:}

1. Ермолаев А.П. Шулика Т.О. Соколова М.А. Основы пластической культуры архитектора-дизайнера: Учеб. пособие. / Ермолаев А.П. и др. - М.: Архитектура-С, 2005. - 464 с.

2. Симон Анвин. Основы архитектуры . -Питер,2012.-272 с. 